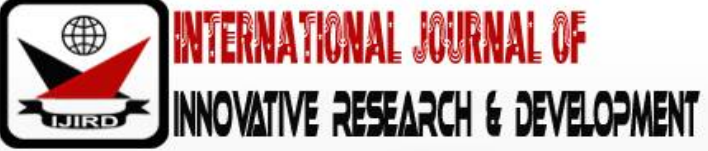

ISSN 2278 - 0211 (Online)

\section{Impact of Poverty Alleviation Programme on Job Creation and Income Generation in Yobe State, Nigeria}

Samaila Mohammed Tomsu
Principal Investment Officer, Department of Investment and Public, Private Partnership,
University of Maiduguri, Borno State, Nigeria
Idris Mu'azu
Lecturer, Department of Sociology and Anthropology,
University of Maiduguri, Borno State, Nigeria
Suleiman Umar
Senior Programme Analyst, Directorate of Computer Centre (ICT),
University of Maiduguri, Borno State, Nigeria

\begin{abstract}
:
The study assessed the impact of poverty alleviation programmes in Yobe state. The Objectives of the study is to assessthe impact of poverty alleviation on job creation and income generation. And the beneficiaries of this study are the Yobe State Agency for Community and Social Development, Ministry of Sport and Youth Empowerment, Non-Governmental Organization Eradicating Poverty, Youths/ Adult, Farmers and School Dropout. A survey research design was used for the study. The target population of the study was comprise of 300 beneficiaries of poverty alleviation programmes in Damaturu Local Government Area, one hundred and sixty nine (169) was selected as sample through simple random sampling techniques. The instrument used for this study was questionnaire tagged Assessment of Poverty Alleviation Programmes on Adults Economic in Empowerment in Damaturu, Yobe State (APAPAEED). In analyzing the data descriptive statistics of frequency, percentage, mean and Ranks was used. The study reveals that Poverty Alleviation Programmes has positive impacts on job creation and income generation in Damaturu, Yobe State, Nigeria.
\end{abstract}

Keywords: Poverty alleviation, job creation, income generation, youths, empowerment

\section{Introduction}

Poverty is a pervasive phenomenon worldwide. The increasing trend in the level of poverty has been a leading public issue in recent times (Ogbuabor, Malaolu, Elias 2013). Poverty is very wide and due to its vastness it is believed that, there is no general consensus of any single definition of what it amounts to what can be called poverty, this is simply because it affects many aspects of human condition which can be physical, moral and psychological.Nigeria economic report released in July 2014 by the World Bank put poverty rate at $33.1 \%$ for a country with massive wealth and a huge population to support commerce. The report seems inconsistent with reality. Income inequality worsened from 0.43 to 0.49 between 2004 and 2009. The report also shows that, the dept and severity of poverty is more in the rural than in the urban. Poverty is an economic and social problem, most especially in the third world countries, in Nigeria it is assuming a worrisome dimension as empirical evidence have shown that Nigeria, a sub Saharan Africa country has at least half of its population in abject poverty. However, arriving at a definite and generally acceptable definition of poverty has always been a problem because the concept of poverty means different things to different people or different groups of people. According to United Nation (1998) cited in Onwe and Chibuzor (2015) poverty is fundamentally a denial of choices and opportunities, a violation of human dignity. It means lack of basic capacity to participate effectively in society. It means not having enough to feed and clothe a family, not having a school or clinic to go to, not having the land on which to grow one's food or a job to earn one's living, not having access to credit. It means insecurity, powerlessness and exclusion of individuals, households and communities. It means susceptibility to violence, and it often implies living on marginal or fragile environments, without access to clean water or sanitation. (UN statement, June 1998 - signed by the heads of all UN agencies), In Nigeria, corruption, unemployment, unfavorable business environment, wrong implementation of privatization programs, wrong patterns of education, political instability, poor macroeconomic policies, incessant cases of inflation, harsh economic reforms leading to retrenchments, among others, are some of the main causes of poverty (Obadan, 1996).

In 1999, the Federal Government of Nigeria observed that poverty was on the increase in Nigeria despite the large number of on-going efforts and programmes to fight poverty. Although past regimes in Nigeria had attempted to tackle poverty through the creation of institutions and agencies such as Bank of Agriculture, Development Bank, Family Economic Advancement programme (FEAP), River Basin Authorities, Operations Feed the Nation, Rural Banking, 
Universal Basic Education (UBE), Directorate of Food, Roads and Rural Infrastructure (DFRRI) National Directorate of Employment (NDE) and similar agencies, with the view to empower the participants, yet all of these programme had minimal impact on the people. Hence, the need for the government to tackle the poverty issue headlong.

Job creation for unemployed youths is one of the greatest assets that any nation can have. Not only are they legitimately regarded as the future leaders, they are potentially and actually the greatest investment for a country's development. The extent of their volatility, responsible conduct and role in the society is positively correlates with development. According to Holmes (2013), there is a strong empirical evidence that employment creation generally increases incomes and reduces poverty in low-income countries at both micro and macro levels, and a significant body of research decomposes the effect of various factors on poverty, Yobe state's population is predominantly youths according to the Ministry. Therefore, the government has given due consideration to youth in socio-economic and political development, the focus therefore, is to generate maximum expression of youthful creativity, productivity, ingenuity and freedom in the context of an appropriate environment for self-expression, self-sustenance and self-actualization and empowerment by the youth. (Yamta 2014). The linkages among education, poverty, unemployment, income inequality and economic growth in an economy have been discussed in many studies. According to Akpoko et al(1998) study of impact of a non-governmental agricultural extension training programme there was a significant impact on the youth's livelihood in terms of ownership of commercial vehicles, motor-cycles, bicycles, clothing, food crops and food consumption as a result of their participation in the programme. Similarly, Fasina et al(2004) cited in Ebenehi (2012) states that the previously unemployed youths were able to secure a better level of living as a result of their participation in the empowerment scheme. The study further showed that access to poverty alleviation programmes improved socio-economic status of youths and promote their economic independence.Income Generation Is the process used to describe an investment or business activity that makes money through skills utilization, this is about ensuring the most effective application of skills in the work place to maximize performance through the interplay of a number of key agents (e.g. employers, employees, learning providers and the state) and the use of a range of human resource, management and working practices. Therefore, income can be generated by self-employment, by working for others or by adding to personal resources through investment. According to study conducted by Abubakar (2010), on contribution of skills acquisition centres to poverty alleviation in Taraba State, the study found that it has helped in the alleviation of poverty by increasing participant income generation, in a similar vein, Michel and Nathan (2013) conducted a study on impact of poverty alleviation programmes on economic growth and income generation in Yenagoa, Bayelsa state the study examine the success of poverty alleviation on income generation among youths in the state, the findings depicts that, the strategy has enhanced their income and empowered them. Similarly, Saddiq et al (2015) described as remarkable and significant the impact of NAPEP on the income and standard of living of participants in Kogi State. The mean income of NAPEP participants increased by 48 per cent after the intervention. In realization of the above, efforts of successive governments at both federal and state level was geared towards provision of effective youths empowerment schemes aimed at job creation to enhance income generation among the people. This empowerment scheme has adopted an approach to poverty alleviation based on recent understanding that livelihood strategies centered not only on the use of a range of natural, material and economic resources, but also social and cultural resources as empowerment tools. Yobe State Government has over the years been developing and implementing various project and programmes in its development rolling plans and Budget aimed at meeting the needs of citizenry and therefore reducing poverty. With the creation of Yobe State in 1992, most Yobe State citizens returned home, and within short- time there came population explosion, with high level of unemployment, destitution and general sense of hopelessness and other social values. To address this phenomenon the Yobe state Agency for Community and Social Development, under the Ministry of Youth, Sport and Social Development was charged with the responsibility of addressing unemployment and wide spread poverty through programmes that targeted at income and employment generation, provision of portable drinking water, functional education health care delivery services, agriculture and empowerment of youths through job creation. Since the establishment of the Ministry of Youth, Sport and Social Development and the implementation of its poverty alleviation and empowerment programmes in the area. Despite, the efforts there is still public outcry that, much has not been achieved, as the schemes are usually said to be hijacked by politicians and their associates, friends and family, thus rendering it ineffective as most of the deserving beneficiaries are excluded from the schemes. It is on this note that this study assessed the impact of poverty alleviation programmes on adult economic empowerment among the residence of Damaturu metropolitan Yobe State.

\section{Objectives of the Study}

The study assessed the impact Poverty alleviation on job creation, also and Poverty alleviation on income generation.

\section{Methodology}

A survey research design was used for the study. The target population of the study comprised of 300 beneficiaries of poverty alleviation programmes in Damaturu Local Government Area, One hundred and sixty nine (169) beneficiaries were selected as sample through simple random sampling techniques base on Kreicie \&Morgan (2006) sample size estimation formula. The researcher used a self designed questionnaire validated by expert and tagged "Assessment of Poverty Alleviation programme on Adult Economic Empowerment Questionnaire (APAPAEEQ).The reliability of the instrument was done using test-retest. The result was coefficient. The retrieved questionnaires were analysed using descriptive statistics, frequency, and percentage, mean and Ranks. 


\section{Results and Discussion}

- $\quad$ Research Question 1: What is Impact of poverty alleviation programme on job creation for unemployed youths?

\begin{tabular}{|c|c|c|c|c|c|c|c|c|}
\hline $\mathbf{S} / \mathbf{N}$ & Items/variables & $\begin{array}{c}\text { SA } \\
\text { Freq. (\%) }\end{array}$ & $\begin{array}{c}A \\
\text { Freq. (\%) }\end{array}$ & $\begin{array}{c}D \\
\text { Freq. (\%) }\end{array}$ & $\begin{array}{c}\text { SD } \\
\text { Freq. (\%) }\end{array}$ & $\begin{array}{c}\text { Total } \\
\text { Freq. }(\%)\end{array}$ & Mean & Ranks \\
\hline 1. & $\begin{array}{l}\text { I have acquired skills } \\
\text { that can make me self } \\
\text { employed }\end{array}$ & $63(37.2)$ & $41(24.2)$ & $53(31.3)$ & $12(7.1)$ & $169(100)$ & 2.91 & 5 \\
\hline 2. & $\begin{array}{l}\text { I now have a better } \\
\text { chance of getting } \\
\text { employed as a result of } \\
\text { skill I have acquired }\end{array}$ & $73(43.1)$ & $86(50.8)$ & $\begin{array}{ll}9 & (5.3)\end{array}$ & $1 \quad(0.59)$ & $169(100)$ & 3.37 & 2 \\
\hline 3. & $\begin{array}{l}\text { I have acquired skills } \\
\text { that can make me } \\
\text { employ a few others }\end{array}$ & $81(47.9)$ & 81 47.9) & $\begin{array}{ll}6 & (3.5)\end{array}$ & $1 \quad(0.59)$ & 169 (100) & 3.43 & 1 \\
\hline 4. & $\begin{array}{l}\text { I have acquired skills } \\
\text { that can make me start } \\
\text { my own business }\end{array}$ & 63 (37.2) & 99 (58.5) & $\begin{array}{ll}6 & (3.5)\end{array}$ & $1 \quad(0.5)$ & $169(100)$ & 3.32 & 3 \\
\hline 5. & $\begin{array}{l}\text { Poverty alleviation } \\
\text { programme has been } \\
\text { given me facilities to set } \\
\text { up a workshop }\end{array}$ & 65 (38.4) & 91 (53.8) & $\begin{array}{ll}9 & (5.3)\end{array}$ & $\begin{array}{ll}4 & (2.3)\end{array}$ & $169(100)$ & 3.28 & 4 \\
\hline & Total & 345 & 398 & 83 & 19 & 845 & & \\
\hline & Overall mean & & & & & & 3.20 & \\
\hline
\end{tabular}

Table 1: Distribution of Responses on Impacts of Job Creation for Employed Youths in Damaturu

Source: Field Survey (2018)

\subsection{Figures in Parenthesis are the Percentages}

The data in table 1 shows the impact of job creation for unemployed youths. Item (1) in the table respondent where asked to if they acquired any skills before the poverty alleviation programme. Out of one hundred and sixty nine respondents, one hundred and four respondents representing sixty one point five percent (61.5) agreed that before the poverty alleviation programme, they tent have any skills to make themselves employed, while sixty five respondents (65) representing thirty eight point five percent (38.5) disagreed with the statement. In the item two (2), the respondent where asked through poverty alleviation programme, if they have chance of getting employed, out of one hundred and sixty nine respondents (169), one hundred and fifty nine respondent (159) representing ninety four percent (94.1\%) agreed to the statement while ten (10) representing five point nine percent (5.9) disagreed with the statement. In item three (3), the respondents were asked if the skills acquired in poverty alleviation programme will make them employed others. One hundred and sixty two (162) respondent representing nine five point eight percent (95.8\%) agreed with the statement while seven (7) of the respondent representing four point one (4.1\%) percent to agreed with the statements. In item five (5) the respondent were asked whether the poverty alleviation programme has given them facilities to set up workshop out of one hundred and sixty nine (169) respondents one hundred and fifty six (156) respondent representing ninety two point three (92.3) agreed that poverty alleviation programme has given them facilities to start up workshop, while thirteen (13) of the respondent representing seven point six (7.6\%) disagreed with the statement, and the overall mean is 3.20. Therefore, the analysis on the table 1 revealed that poverty alleviation programme on job creation has positive impact on the unemployed youths of Damaturu.

- Research question 2: What is Impact of poverty alleviation programme on Income Generation?

\begin{tabular}{|c|c|c|c|c|c|c|c|c|}
\hline S/ N & Items/ Variables & $\begin{array}{c}\text { SA } \\
\text { Freq. (\%) }\end{array}$ & $\begin{array}{c}\text { A } \\
\text { Freq. (\%) }\end{array}$ & $\begin{array}{c}\text { D } \\
\text { Freq. (\%) }\end{array}$ & $\begin{array}{c}\text { SD } \\
\text { Freq. (\%) }\end{array}$ & $\begin{array}{c}\text { Total } \\
\text { Freq. (\%) }\end{array}$ & Mean & Ranks \\
\hline 1. & $\begin{array}{c}\text { I now earn an income rate which } \\
\text { I never I have earn before }\end{array}$ & $53(31.3)$ & $51(30.1)$ & $53(31.3)$ & $12(7.1)$ & $169(100)$ & 2.85 & 5 \\
\hline 2. & $\begin{array}{c}\text { The income I now earn enable me } \\
\text { solve more of my problems }\end{array}$ & $53(31.3)$ & $100(59.1)$ & $15(8.8)$ & $1(0.5)$ & $169(100)$ & 3.21 & 4 \\
\hline 3. & $\begin{array}{c}\text { The income I now earn, is far } \\
\text { higher than before }\end{array}$ & $70(41.4)$ & $90(53.2)$ & $8(4.7)$ & $1(0.5)$ & $169(100)$ & 3.35 & 3 \\
\hline 4. & $\begin{array}{c}\text { With my current earning, Inow } \\
\text { have a higher standard of living }\end{array}$ & $60(35.5)$ & $93(55.0)$ & $15(8.8)$ & $1(0.5)$ & $169(100)$ & 3.25 & 2 \\
\hline 5. & $\begin{array}{c}\text { My prestige has increased with } \\
\text { my current earning }\end{array}$ & $70(41.4)$ & $91(53.8)$ & $4(2.3)$ & $4(2.3)$ & $169(100)$ & 3.34 & 1 \\
\hline & Total & 306 & 425 & 95 & 19 & 845 & & \\
\hline & Overall mean & & & & & & 3.20 & \\
\hline
\end{tabular}

Table 2: Distribution of Responses on Impact on Income Generation

Source: Field Survey (2018) 


\subsection{Figures in Parenthesis are the Percentages}

Table 2: The researcher sought to know the impact of PAP on income generation. In item (1) the respondents were asked whether they can earn an income rate which they earn before as a result of PAP. Out of one hundred and sixty nine (169) respondents one hundred and four (104) respondents representing sixty one point five (61.5\%) percent agreed with the statement while sixty five (65) respondents representing thirty eight point four (38.4\%) percent disagreed with the statement. In item two (2) the respondent were asked if the income they now earn solve more of their problems, out of one hundred and sixty nine (169) respondents, one hundred and fifty three (153) respondents representing ninety four point five (94.5\%) percent agreed with the statement while sixteen (16) respondent representing nine point four $(9.4 \%)$ disagreed with the statement. In item 3 the respondent were asked if the income they now earn is far better than before as a result of PAP, out of one hundred and sixty nine (169) respondent one hundred and sixty (160) respondents representing ninety four point six (94.6\%) percent agreed with the statement while nine (9) respondents representing five point three (5.3\%) percent disagreed with the statement. In item four (4) the respondents were asked with amount earning they high standard of living, out of one hundred and sixty nine (169) respondents, one hundred and fifty three (153) respondents representing ninety point five (90.5\%) percent agreed with the statement while sixteen (16) respondents representing nine point four $(9.4 \%)$ percent disagreed with the statement. In item five (5) the respondents were asked whether their present has increase with current earning, out of one hundred and sixty nine (169) respondents representing ninety point five (90.5\%) agreed while eight (8) of the respondent representing four point seven (4.7\%) disagreed with the statement, and the overall mean is 3.20 .

Therefore, poverty alleviation programme (PAP) on income generation has impacted positively on the adults and youths of Damaturu, Yobe state.

\section{Discussion}

The first objective was to know the impact on job creation for unemployed youths have reduce poverty. This was because the respondents agreed with $87.9 \%$ of total mean percentage while $12.1 \%$ disagreed. This implies that many youths have been trained in various skills and are empowered to set up their business. The findings coincides with Funmilola (2009), studied on the impact of youth empowerment scheme on poverty alleviation in Borno State. The study revealed that youth empowerment scheme have made significant contribution towards improving the standard of the beneficiaries and the overall mean which is 3.20 shows the findings is positive.

The findings on income generation shows that $86.5 \%$ of the total mean percentage agreed that they now earn an income while they never earning before, and the current earn has increased has solve their problems, increased their prestige and standard of living while 13.5\% disagreed the findings ofAbubakar (2010), study that fund that the contribute on skills acquisition centres to poverty alleviation in Taraba State, has helped in the alleviation of poverty by increasing participant income generation. The overall mean is 3.20 that show the finding has positive impact on the beneficiary.

The findings of the study on assessment of impact of poverty alleviation programmes on adult's economic empowerment in Damaturu, Yobe State showed that it has impacted positively on the lives of the beneficiaries. The study agreed with UNESCO (2003), on income generation programmes for poverty alleviation, when it observed poverty alleviation programme serve as the basic of force attack to poverty. This is because these programmes are essentially aimed at generating incremental incomes for the have poor. It was recognized that a traumatic increase in income is by itself not enough to improve the quality of the poor, unless all citizens especially the poor have certain basic care, safe drinking water and natural security. The study also conducted by Orji (2008), on an assessment of impact of poverty reduction programmes in Nigeria (1970-2005) show the programme have failed because the programme lack mechanisms for the poor and not focus directly on the poor mismanagement and bad governors afflicted the programme resulting in facilities/ infrastructure not been completed or not even established among others.

The results of the data analyses shows that; Government has provided modern agricultural technology, inputs and improved seeds, create job opportunities for unemployed youths the literacy programmes has reduced the rate of poverty in the state. The study also showed that income generation has impacted positively on the beneficiaries.

\section{Conclusion}

Based on the major findings of the study, it was concluded that, the identified poverty alleviation programmes have reduced poverty. This implies that poverty alleviation programmes on youth and economic empowerment have improved the living standard of the beneficiaries.

\section{Recommendations}

The following recommendations were made to improved the living standard of the people and reduce poverty in the society.

- Government should establish more vocational training centres and provide sufficient poverty reduction that will be efficient as to increase employment and income generation.

- There is need to encourage and create more awareness of employment opportunities, income generation, wealth creation and skills acquisition for youths.

\section{References}

i. Abubakar, I. R. (2010). The contribution of skills acquisition centre to poverty Alleviation in Taraba State, Nigeria. Dissertation submitted for the award of M.Ed (Administration and Planning) Department of Continuing and Extension Services, University of Maiduguri. 
ii. Akpoko, J. G., Auta, S. J and Arokoyo, J. T. (1998). The Impact of Non- GovernmentalAgricultural Extension Training programmes: A Case study of the NigerianTobacco Company, Zaria. Nigeria. Journal of Agricultural Extension, zariaNigeria: (1 and 2): 97-110.

iii. Holmes R Anna McCord A G and Zanker F (2013) The Evidence of the Impact of Employment CreationStability and Poverty Reduction in Fragile States Overseas. Development Institute 203 BlackfriarsRoad, London SE1 8NJ, UKILO. (2014). Wages and working hours in the textiles, clothing, leather and footwear industries.

iv. Kreicie, R.V. \& Morgan, D.W (2006). Determining Sample size for Research activities.Educational and Psychological Measurement, obtained from http/ / www.fns.usda.gov

v. Michel and Nathan (2013) impact of poverty alleviation programmes on economic growth and income generation in Yenagoa, Bayelsa

vi. Obadan M.I. (2001). Poverty Reduction in Nigeria: The way forward. CBN Economic and financial Reviewvol.39 No. 4.

vii. Ohinze E. \& Adamu, M. J. (2009). Department of international and Technology Education Federal University Technology Minna, Niger State.

viii. Orji. A. (2008) An Assessment of impact of poverty reduction programmes in Nigeria,

ix. Olufunke, A. M. (2011). Literacy: A potent for Women Empowerment. International review of social sciences and humanities. 1, (2). Available at: www.irsh.com (accessed 21/ 09/ 2014).

x. Ogbuabor, and Victor A. Malaolu Department of Economics, University of Nigeria, Nsukka, Enugu State, NigeriaCBN Entrepreneurship Development Centre (EDC), Ikeja Lagos, Nigeria E-mail of the corresponding author: jonathan.ogbuabor@unn.edu.ngOnwe, Chibuzor Onwe (Ph.D, Fcai) and Nwakama Michel Chibuzor (2015)Department of Public Administration Ebonyi State University Abakaliki, Nigeria

xi. UN, (1998). Gender Equality Matters: Empowering Women Through Literacy Programmes. Available From: www.unesdoc.unesco.org (accessed 6/ 1/ 1998)

xii. World Bank (2002), Poverty Reduction and the World Bank Progress in Operationalizing theWDR 2000/ 2001 World Bank Washington

xiii. Yamta (2014). Assessment of Impact of Poverty Alleviation Programmes in Borno State, Nigeria. Thesis submitted for the award of PhD (Community Development and Social Welfare) Department of Continuing and Extension Services, University of Maiduguri. 